\title{
A Survey of Sex Chromatin Abnormalities in Mental Hospitals
}

\author{
N. MACLEAN, W. M. COURT BROWN, PATRICIA A. JACOBS, \\ D. J. MANTLE, and J. A. STRONG \\ From the Department of Pathology, the M.R.C. Clinical Effects of Radiation Research Unit, \\ and the Department of Medicine, Western General Hospital, Edinburgh
}

Sex chromatin surveys have shown that an additional X chromosome is present in some or all of the cells of about 1 in 500 newborn males and of about 1 in 1000 newborn females, and that these anomalies may be 4-5 times commoner in inmates of mental deficiency institutions. The present survey was undertaken to determine the frequency of $\mathrm{X}$ chromosome abnormalities in patients with other mental disorders. It soon became obvious that the incidence was greater than that in the newborn population, and that it varied considerably from one hospital to another. The survey was, therefore, extended to embrace a population sufficiently large to eliminate gross sampling errors. Results were obtained in 6000 male and 6241 female in-patients of mental hospitals in Scotland, and in 966 female outpatients of a psychiatric clinic.

\section{Techniques}

A modification of the buccal smear method of Moore and Barr (1955) was used to determine the nuclear sex (Maclean, 1966). Chromosomes of blood lymphocytes were studied by a modification of the technique of Moorhead et al. (1960). The method of Harnden (1960) was used for fibroblast cultures of the skin. Physical examination of patients with abnormal buccal smears was carried out by one of us (D.J.M.), and their psychiatric assessment was given by the Physician-Superintendents of the hospitals concerned. Analysis of diagnostic categories in each hospital was supplied by the Research and Intelligence Unit of the Scottish Home and Health Department.

\section{Results}

Males. 30 of 6000 males were chromatin positive $(0.5 \%)$. Chromosome studies were carried out on 28 of them, and the results of these studies

Received September 28, 1967. are given in Table I. 19 proved to have an XXY sex chromosome constitution. 5 (Cases 22-26) had both an XY and an XXY cell line and one of them (Case 24), who was the father of 2 children, has been reported in detail (Court Brown et al., 1964b). 2 additional patients (Cases 21 and 27) had more complex forms of mosaicism. One mentally defective patient (Case 28) had an XXXY/XXXXY sex chromosome constitution. In Case 20 the nuclear sex was at variance with the apparent chromosome constitution. Only an XY cell line could be demonstrated in cultures of the blood and skin, and no drumsticks were seen in 1000 neutrophil polymorphs, but buccal smears were chromatin positive on repeated occasions. The patient was mentally defective and psychotic, with a history of congenital syphilis and no signs of hypogonadism. It is evident that in this patient XY cells predominate, but it is presumed that another cell line, probably XXY, is also present in some of the tissues.

In 2 patients it was not possible to obtain material for chromosome studies. In one of them, $49 \%$ of suitable cells of the buccal smear were chromatin positive and the sex chromosome constitution is assumed to be XXY. In the other, only $13 \%$ of suitable cells of the buccal smear were chromatin positive. Such a low proportion of chromatinpositive cells in satisfactory buccal smears has in past experience in this centre been indicative of mosaicism (Court Brown et al., 1964a; Maclean, 1966), and in this case the most reasonable presumption is that both $\mathrm{XY}$ and $\mathrm{XXY}$ cell lines are present. Of the total 30 chromatin-positive male patients, therefore, 20 are presumed to have an XXY sex chromosome constitution, and 10 to have more than one cell line.

Of the 30 chromatin-positive males, 10 were mentally defective and 2 of these were also believed to be suffering from schizophrenia. 11 others 
TABLE I

SEX CHROMATIN POSITIVE MALES IN MENTAL HOSPITALS

\begin{tabular}{|c|c|c|c|c|c|c|c|c|c|}
\hline \multirow{2}{*}{$\begin{array}{l}\text { Case } \\
\text { No. }\end{array}$} & \multirow{2}{*}{$\begin{array}{l}\text { Date of } \\
\text { Birth }\end{array}$} & \multicolumn{2}{|c|}{ Sex Chromosomes } & \multicolumn{3}{|c|}{$\begin{array}{c}\text { Percentage of Oral } \\
\text { Cells with Barr } \\
\text { Bodies (BB) }\end{array}$} & \multirow{2}{*}{$\begin{array}{l}\text { Marital } \\
\text { Status }\end{array}$} & \multirow{2}{*}{ Gynaecomastia } & \multirow{2}{*}{ Psychiatric Diagnosis } \\
\hline & & Blood & Skin & $1 \mathrm{BB}$ & 2 BBs & $3 \mathrm{BBs}$ & & & \\
\hline $\begin{array}{l}1 \\
2 \\
3 \\
4 \\
5 \\
6 \\
7 \\
8 \\
9\end{array}$ & \begin{tabular}{|r|}
23.2 .1911 \\
19.6 .1913 \\
15.9 .1912 \\
25.31889 \\
10.11 .1904 \\
16.4 .1884 \\
26.61913 \\
22.1 .1879 \\
7.2 .1905
\end{tabular} & $\begin{array}{l}\text { XXY } \\
\text { XXY } \\
\text { XXY } \\
\text { XXY } \\
\text { XXY } \\
\text { XXY } \\
\text { XXY } \\
\text { XXY } \\
\text { XXY }\end{array}$ & $\begin{array}{l}X X Y \\
X X Y\end{array}$ & $\begin{array}{l}70 \\
49 \\
61 \\
40 \\
48 \\
61 \\
60 \\
44 \\
45\end{array}$ & & & $\begin{array}{l}\mathbf{S} \\
\mathbf{S} \\
\mathbf{S} \\
\mathbf{S} \\
\mathbf{S} \\
\mathbf{M} \\
\mathbf{S} \\
\mathbf{S} \\
\mathbf{S}\end{array}$ & $\begin{array}{l}\bar{z} \\
\overline{\bar{Z}} \\
\text { slight }\end{array}$ & $\begin{array}{l}\text { Mental deficiency; schizophrenia } \\
\text { ? Schizophrenia; deaf mute } \\
\text { Mental deficiency } \\
\text { Schizophrenia } \\
\text { Schizophrenia } \\
\text { Arteriosclerotic dementia } \\
\text { Mental deficiency with mania } \\
\text { Senile pyychosis } \\
\text { Mental deficiency; paranoid }\end{array}$ \\
\hline $\begin{array}{l}10 \\
11 \\
12 \\
13 \\
14 \\
15\end{array}$ & $\begin{array}{r}3.1 .1887 \\
15.5 .1893 \\
10.9 .1899 \\
8.4 .1921 \\
11.6 .1904 \\
22.1 .1913\end{array}$ & $\begin{array}{l}\text { XXY } \\
\text { XXY } \\
X X Y \\
X X Y \\
X X Y \\
X X Y \\
\text { XXY }\end{array}$ & $\begin{array}{l}\mathbf{X X Y} \\
\mathbf{X X Y}\end{array}$ & $\begin{array}{l}50 \\
53 \\
35 \\
51 \\
68 \\
60\end{array}$ & & & $\begin{array}{l}M \\
\mathbf{M} \\
\mathbf{S} \\
\mathbf{S} \\
\mathbf{S}\end{array}$ & $\begin{array}{l}\text { Slight } \\
\text { Marked } \\
\text { Slight } \\
\text { Slight }\end{array}$ & $\begin{array}{l}\text { schizophrenia } \\
\text { Arteriosclerotic dementia } \\
\text { Delusional insanity } \\
\text { Paranoid schizizophrenia } \\
\text { Paranoid state } \\
\text { Schizophrenia } \\
\text { Mental deficiency; chronic }\end{array}$ \\
\hline $\begin{array}{l}16 \\
17 \\
18 \\
19 \\
20 \\
21 \\
22 \\
23 \\
24 \\
25 \\
26\end{array}$ & $\begin{array}{r}14.9 .1916 \\
15.3 .1944 \\
8.12 .1904 \\
28.8 .1924 \\
23.3 .1913 \\
8.8 .1893 \\
4.5 .1887 \\
30.9 .1909 \\
11.6 .1898 \\
12.8 .1898 \\
1.7 .1887\end{array}$ & $\begin{array}{l}\text { XXY } \\
\text { XXY } \\
X X Y \\
\text { XXY } \\
\text { XY } \\
\text { XY } \\
\text { XY/XXY } \\
\text { XY/XXY } \\
\text { XY/XXY } \\
\text { XY/XXY } \\
\text { XY/XXY }\end{array}$ & $\begin{array}{l}\mathbf{X Y} \\
\mathbf{X O} / \mathbf{X Y} / \mathbf{X X Y} \\
\mathbf{X Y} / \mathbf{X Y} \\
\mathbf{X Y} / \mathbf{X X Y} \\
\mathbf{X Y} / \mathbf{X X Y} \\
\mathbf{X Y} / \mathbf{X X Y}\end{array}$ & $\begin{array}{l}62 \\
52 \\
59 \\
69 \\
30 \\
44 \\
44 \\
56 \\
52 \\
48 \\
48\end{array}$ & & & $\begin{array}{l}\mathbf{S} \\
\mathbf{S} \\
\mathbf{S} \\
\mathbf{S} \\
\mathbf{S} \\
\mathbf{S} \\
\mathbf{S} \\
\mathbf{M} \\
\mathbf{M} \\
\mathbf{S}\end{array}$ & $\begin{array}{l}\text { Marked } \\
\text { Slight } \\
\text { Marked } \\
\text { Marked } \\
\overline{=} \\
\text { Marked } \\
=\end{array}$ & $\begin{array}{l}\text { Epileptic psychosis } \\
\text { Psychopath } \\
\text { Schizophrenia } \\
\text { Mental deficiency } \\
\text { Mental deficiency } \\
\text { Epileptic insanity } \\
\text { Schiziophrenia } \\
\text { Epilepsy } \\
\text { Paranoid schizophrenia } \\
\text { Delusional insanity } \\
\text { Mental deficiency; cerebral }\end{array}$ \\
\hline $\begin{array}{l}27 \\
28 \\
29 \\
30\end{array}$ & $\begin{array}{r}20.1 .1909 \\
10.5 .1837 \\
1898 \\
2.2 .1925\end{array}$ & $\begin{array}{c}\mathrm{xy} \\
\mathrm{xxxy} / \mathrm{XXXXY} \\
\text { NO CUL } \\
\text { NO CUL }\end{array}$ & $\begin{array}{l}\mathrm{XY} / \mathrm{XXY} / \mathrm{XXXY} \\
\mathbf{X X X Y / X X X X Y} \\
\text { LTURES } \\
\text { LTURES }\end{array}$ & $\begin{array}{l}18 \\
47 \\
49 \\
13\end{array}$ & 33 & 7 & $\begin{array}{l}\mathbf{S} \\
\mathbf{M} \\
\mathbf{S}\end{array}$ & $\begin{array}{c}\bar{Z} \\
\text { Not known } \\
\text { Not known }\end{array}$ & $\begin{array}{l}\text { arteriosiclerosis } \\
\text { Mennid schizophrenia } \\
\text { Mental deficiency with mania } \\
\text { Mental deficiency } \\
\text { Paranoid schizophrenia }\end{array}$ \\
\hline
\end{tabular}

$\star M$, married; $S$, single.

also suffered from schizophrenia as their major disability. 3 additional patients suffered from epilepsy, and the remainder from a variety of disorders including cerebral arteriosclerosis (2 cases), senile psychosis ( 1 case), psychopathic personality ( 1 case), and 'delusional insanity' ( 2 cases).

Females. Of the 6241 female in-patients, $15(0.24 \%)$ had 2 sex chromatin bodies in some of the cells of their buccal smears, and 2 of the 966 $(0.21 \%)$ out-patients were similarly affected (Cases 41 and 46). Thus, $0.24 \%$ of the 7207 women examined while they were under psychiatric care at Scottish Mental Hospitals had $3 \mathrm{X}$ chromosomes in some or all of their cells (Table II). None of the other women was chromatin negative or had sex chromatin bodies which were thought to be abnor$\mathrm{mal}$ in size.

Chromosome studies were made on 16 of the 17 women with abnormal buccal smears. 12 of the 16 had an uncomplicated XXX sex chromosome constitution. 2 (Cases 43 and 44) had both XX and $\mathrm{XXX}$ cell lines in blood and skin cultures. Cases 45 and 46 were examples of XO/XXX mosaicism. Chromosome studies could not be made in Case 47 and it is not possible to be certain that in her case $\mathrm{XXX}$ is the only cell line present.

Of the 17 female patients with abnormal buccal smears, 4 were mentally defective, and 3 of them were unstable, one depressive, another psychopathic, and the third schizophrenic. 6 additional patients suffered from schizophrenia, and 3 more had depressive illnesses. Cerebral arteriosclerosis was diagnosed in 2 of the 4 remaining patients, and senile psychosis in the other 2 .

Classification by Disease. The analysis of the various categories of disease is based upon a classification made in accordance with the International Classification of Disease, 7th edition, at about the mid-point of the survey (June 1, 1963), a time when 6343 males and 7028 females were resident in the hospitals surveyed. Complete survey was not possible for a number of reasons: in some cases the patient refused consent for the examination; in others the patient was for one reason or another out of hospital at the time of the visit; other cases were lost when unsatisfactory initial buccal smears could not be repeated because the patient had been discharged. Results were in fact ob- 
TABLE II

FEMALES WITH ABNORMAL SEX CHROMATIN UNDER PSYCHIATRIC CARE

\begin{tabular}{|c|c|c|c|c|c|c|c|c|c|}
\hline \multirow{2}{*}{$\begin{array}{l}\text { Case } \\
\text { No. }\end{array}$} & \multirow{2}{*}{$\begin{array}{l}\text { Date of } \\
\text { Birth }\end{array}$} & \multicolumn{2}{|c|}{ Sex Chromosomes } & \multicolumn{2}{|c|}{$\begin{array}{l}\text { Percentage of Oral Cells } \\
\text { with Barr Bodies (BB) }\end{array}$} & \multirow{2}{*}{$\begin{array}{l}\text { Marital } \\
\text { Status }\end{array}$} & \multirow{2}{*}{ Menstruation } & \multirow{2}{*}{$\begin{array}{l}\text { No. of } \\
\text { Offspring }\end{array}$} & \multirow{2}{*}{ Psychiatric Diagnosis } \\
\hline & & Blood & Skin & $1 \mathrm{BB}$ & $2 \mathrm{BBs}$ & & & & \\
\hline $\begin{array}{l}31 \\
32 \\
33 \\
34\end{array}$ & \begin{tabular}{|l|}
26.5 .1893 \\
4.1 .1921 \\
19.8 .1929 \\
10.2 .1909
\end{tabular} & $\begin{array}{l}\mathrm{xxy} \\
\mathrm{xxx} \\
\mathrm{xxx} \\
\mathrm{xxx}\end{array}$ & \multirow[b]{2}{*}{$\mathbf{x x x}$} & $\begin{array}{l}53 \\
52 \\
55 \\
44\end{array}$ & $\begin{array}{l}33 \\
32 \\
22 \\
27\end{array}$ & $\begin{array}{l}\mathbf{S} \\
\mathbf{S} \\
\mathbf{S} \\
\mathbf{S}\end{array}$ & $\begin{array}{c}\text { Never } \\
\text { Normal } \\
\text { Not known }\end{array}$ & $\begin{array}{l}0 \\
0 \\
0 \\
0\end{array}$ & \multirow{5}{*}{\begin{tabular}{|l|} 
Melancholia \\
Schizophrenia \\
Schizophrenia \\
Depression; cerebral \\
thrombosis \\
Schizophrenia \\
Mental deficiency \\
Maranoid schizophrenia \\
Organic psychosis \\
Mental deficiency; \\
depression \\
Senile psychosis \\
Mental deficiency; \\
schiophrenia \\
Depression \\
Schizophrenia \\
Schizophrenia \\
Mental deficiency; \\
psychopathic \\
Depression \\
Senility; alcoholism
\end{tabular}} \\
\hline $\begin{array}{l}35 \\
36 \\
37 \\
38 \\
39\end{array}$ & $\begin{array}{r}12.3 .1916 \\
28.4 .1932 \\
16.7 .1899 \\
8.6 .1908 \\
9.10 .1914\end{array}$ & $\begin{array}{l}x x x \\
x x y \\
x x x \\
x x x \\
x x x\end{array}$ & & $\begin{array}{l}60 \\
54 \\
33 \\
47 \\
51\end{array}$ & $\begin{array}{l}24 \\
26 \\
28 \\
18 \\
30\end{array}$ & $\begin{array}{l}\mathbf{S} \\
\mathbf{M} \\
\mathbf{M} \\
\mathbf{S}\end{array}$ & $\begin{array}{c}\text { Normal } \\
\text { Irregular } \\
\text { Normal } \\
\# \\
\#\end{array}$ & $\begin{array}{l}0 \\
0 \\
3 \\
0 \\
0\end{array}$ & \\
\hline $\begin{array}{l}40 \\
41\end{array}$ & $\begin{array}{r}30.8 .1885 \\
6.4 .1922\end{array}$ & $\begin{array}{l}\operatorname{xxx} \\
\mathbf{x x x}\end{array}$ & $\mathrm{xxx}$ & $\begin{array}{l}40 \\
38\end{array}$ & $\begin{array}{l}36 \\
50\end{array}$ & $\stackrel{M}{\mathbf{M}}$ & $"$ & $\begin{array}{l}\mathbf{0} \\
0\end{array}$ & \\
\hline $\begin{array}{l}42 \\
43 \\
44 \\
45\end{array}$ & \begin{tabular}{|l}
24.9 .1941 \\
18.9 .1905 \\
24.4 .1890 \\
23.8 .1928
\end{tabular} & $\begin{array}{c}x x x \\
x x / x x x \\
x x / x x x \\
x 0 / x x x\end{array}$ & $\begin{array}{l}\mathbf{x x x} \\
\mathbf{x} / \mathbf{x x x} \\
\mathbf{x x} / \mathbf{x x x} \\
\mathbf{x O} / \mathbf{x x x}\end{array}$ & $\begin{array}{l}44 \\
41 \\
52 \\
47\end{array}$ & $\begin{array}{l}36 \\
43 \\
32 \\
35\end{array}$ & $\begin{array}{l}\mathbf{S} \\
\mathbf{S} \\
\mathbf{M} \\
\mathbf{S}\end{array}$ & $\begin{array}{c}\text { Normal } \\
\text { " }\end{array}$ & $\begin{array}{l}0 \\
1 \\
1 \\
1\end{array}$ & \\
\hline $\begin{array}{l}46 \\
47\end{array}$ & $\begin{array}{c}26.2 .1913 \\
1889\end{array}$ & $\underset{\text { No CUI }}{\text { xo/xxx }}$ & $\begin{array}{l}\text { XO/Xxx } \\
\text { TURES }\end{array}$ & $\begin{array}{l}33 \\
40\end{array}$ & $\begin{array}{l}51 \\
36\end{array}$ & $\stackrel{M}{M}$ & Not known & $\begin{array}{l}1 \\
\text { Not known }\end{array}$ & \\
\hline
\end{tabular}

tained from $95 \%$ of the males and $89 \%$ of the female in-patients, and they are believed to be representative. If this is so, the approximate number of patients in the various diagnostic categories may be deduced by reference to the population on June 1 , 1963. Thus 2895 males and 2017 ferrales may be classified as schizophrenic, 479 males and $391 \mathrm{fe}-$ males as mentally defective, and 149 males and 141 females as epileptic. The incidence of abnormal nuclear sex chromatin in these groups is given in Table III.

\section{Discussion}

The results of previous sex chromatin surveys of male mental hospital populations have been reviewed by Hambert (1966) and are set out together with the results of the present investigation in Table IV. In all, 13,852 males were examined and $75(0.54 \%)$ were chromatin positive. Three of the groups studied were composed of schizophrenic patients only, and 9 of these 878 men were chromatin positive $(1.02 \%)$. If these three groups are, for the meantime, omitted from consideration, there is left a general mental hospital population of 12,974 males, which includes 66 chromatin-positive men $(0.51 \%)$. This proportion of abnormalities is higher than the $0.22 \%$ incidence found in 4 independent sex chromatin surveys of newborn boys (Maclean, 1966), and the difference is highly significant $\left(\chi^{2}=17 \cdot 6\right)$.

A number of factors may be concerned in this increase in chromatin-positive males in the general mental hospital population, and the first and most obvious is mental deficiency. Mental hospitals in Scotland and apparently also in Sweden (Hambert, 1966) contain a proportion of mental defectives, and it is estimated that $\mathbf{4 7 9}$ male mental defectives were included in the present survey. Among them were 10 chromatin-positive males $(2.09 \%)$, an incidence which is even higher $\left(\chi^{2}=6.4: 0.02>p>0.01\right)$ than that in 11,613 males in mental deficiency institutions (Ferguson-Smith, 1966). Although the

TABLE III

ESTIMATED INCIDENCE OF ABNORMAL SEX CHROMATIN IN PATIENTS RESIDENT IN MENTAL HOSPITALS IN SCOTLAND

\begin{tabular}{|c|c|c|c|c|c|c|}
\hline \multirow{3}{*}{ Diagnostic Group } & \multicolumn{3}{|c|}{ Males } & \multicolumn{3}{|c|}{ Females } \\
\hline & \multirow{2}{*}{$\begin{array}{c}\text { Estimated No. } \\
\text { in Group }\end{array}$} & \multirow{2}{*}{$\begin{array}{c}\text { Chromatin } \\
\text { No. }\end{array}$} & \multirow{2}{*}{$\begin{array}{c}\text { Positive } \\
\%\end{array}$} & \multirow{2}{*}{$\begin{array}{l}\text { Estimated No. } \\
\text { in Group }\end{array}$} & \multicolumn{2}{|c|}{2 Sex Chromatin Bodies } \\
\hline & & & & & No. & $\%$ \\
\hline $\begin{array}{l}\text { Mental deficiency } \\
\text { Epilepsy } \\
\text { Schizophrenia } \\
\text { Other diagnoses } \\
\text { All groups }\end{array}$ & $\begin{array}{r}479 \\
149 \\
2895 \\
2477 \\
6000\end{array}$ & $\begin{array}{r}10 \\
3 \\
11 \\
6 \\
30\end{array}$ & $\begin{array}{l}2 \cdot 09 \\
2 \cdot 02 \\
0 \cdot 38 \\
0 \cdot 24 \\
0.50\end{array}$ & $\begin{array}{r}391 \\
141 \\
2017 \\
3692 \\
6241\end{array}$ & $\begin{array}{r}4 \\
0 \\
6 \\
5 \\
15\end{array}$ & $\begin{array}{l}1.02 \\
0.00 \\
0.30 \\
0.14 \\
0.24\end{array}$ \\
\hline
\end{tabular}


TABLE IV

SEX CHROMATIN SURVEYS OF MALES IN MENTAL HOSPITALS

\begin{tabular}{|c|c|c|c|c|c|}
\hline \multirow{2}{*}{ Authors } & \multirow{2}{*}{$\begin{array}{l}\text { Hospital } \\
\text { Population }\end{array}$} & \multirow{2}{*}{ Country } & \multirow{2}{*}{$\begin{array}{c}\text { No. } \\
\text { Examined }\end{array}$} & \multicolumn{2}{|c|}{ Chromatin + ve } \\
\hline & & & & No. & $\%$ \\
\hline $\begin{array}{l}\text { Carr, Barr, and Plunkett (1961) } \\
\text { Jagiello (see Polani, 1961) } \\
\text { Tedeschi and Freeman (1962) } \\
\text { Raphael and Shaw (1963) } \\
\text { Nielsen (1964) } \\
\text { Hambert (1966) } \\
\text { Present survey }\end{array}$ & $\begin{array}{c}\text { General mental } \\
\text { Schizophrenic } \\
\text { ", } \\
\text { General mental } \\
\text { ", }\end{array}$ & $\begin{array}{l}\text { U.S.A. } \\
\text { England } \\
\text { U.S.A. } \\
\text { U.S.A. } \\
\text { Denmark } \\
\text { Sweden } \\
\text { Scotland }\end{array}$ & $\begin{array}{r}254 \\
530 \\
248 \\
105 \\
450 \\
6265 \\
6000\end{array}$ & $\begin{array}{r}1 \\
5 \\
3 \\
1 \\
5 \\
30 \\
30\end{array}$ & $\begin{array}{l}0.39 \\
0.94 \\
1.21 \\
0.95 \\
1.11 \\
0.48 \\
0.50\end{array}$ \\
\hline \multicolumn{3}{|l|}{ Combined total } & 13,852 & 75 & 0.54 \\
\hline
\end{tabular}

number of mental defectives in the present series is comparatively small, the difference may be real and may be brought about by selection. Many considerations have to be taken into account in the administrative disposal of mental defectives in need of institutional care; the degree of mental impairment, stability of personality, coexistence of psychosis, and the availability of vacant hospital beds, among others. In the present series the diagnosis of mental deficiency was unqualified in only 4 of the 10 men who were chromatin positive. In 6 there were additional disturbances: schizophrenia in 2; mania in 2; cerebral arteriosclerosis in 1, and alcoholism in the other. These may have been the main factors determining the admission of these patients to mental hospitals, but it is also possible that the level of intellectual development may have influenced their disposal, only the least handicapped being admitted to mental hospitals. There is evidence to suggest that such selection could affect the incidence of sex chromatin abnormalities. Thus in an analysis made by one of us (W.M.C.B.) of published data, the incidence of chromatin-positive males in mental deficiency institutions was found to vary inversely with the degree of intellectual impairment: $0.22 \%$ when the IQ was less than 20 ; $0.90 \%$ when the IQ fell between 20 and 49 ; and $1.5 \%$ when it was over 50 . In a survey of 336 boys in educationally subnormal schools in Zurich, Prader et al. (1958) found an even higher incidence in the children in the IQ range 75-85. 8 were chromatin positive $(2 \cdot 38 \%)$ and had a mean IQ of 79.

Epilepsy may be another factor that influences the incidence of chromatin-positive males in a mental hospital. Hambert (1964) found 4 chromatinpositive cases among 512 males in a Swedish institution for epileptics, and in the present survey 3 of the chromatin-positive males occurred in an estimated population of 149 male epileptics $(2 \cdot 0 \%)$. These are findings that suggest that there is an association ketween the effect of additional $\mathrm{X}$ chro- mosomes in males, and mental disease, and epilepsy, but their significance needs to be tested further by study of large populations of chromatin-positive males, and by observations on epileptics not in need of institutional care.

Schizophrenia may be the third factor causing an excess of chromatin-positive males in mental hospitals, and it is one that gives rise to problems in evaluation. Hambert (1966) stresses the difficulty of precise diagnosis if schizophrenic-like disorders occur in patients with Klinefelter's syndrome, and doubts whether the term schizophrenia has much validity in this context. Schizophrenia in association with Klinefelter's syndrome has, however been described by Money and Hirsch (1963) and be Bond and Margulies (1964), and the results of the surveys of schizophrenic patients noted in Table $\vec{F}$ suggest that the incidence of sex chromatin abnormalities in illnesses so diagnosed is of much the same order as that in mental deficiency. In the mental deficiency surveys reviewed by FergusonSmith (1966), for example, the incidence of sex chromatin abnormalities in 11,613 male mental defectives was $0.84 \%$.

In the present series, 11 of an estimated 2895 males said to be suffering from schizophrenic-like illness were chromatin positive $(0.38 \%)$, and in addition, 2 of the chromatin-positive male mental defectives were also thought to be suffering from schizophrenia. 13 chromatin-positive males were therefore detected among approximately 2900 patients with schizophrenic-like disorders, an incidence that is approximately double that in the newborn male population, and that differs significantly $\left(\chi^{2}=7.0: \mathrm{p}=0.01\right)$ from that of the newborn males in the Edinburgh survey (see Table VI).

The evidence at present available, therefore, suggests that there is an increase in the incidence of abnormal sex chromatin in schizophrenic males as compared with the general population, even when allowance is made for imprecision of diagnosis. Whether this increase is especially related to 
TABLE V

SEX CHROMATIN SURVEYS OF FEMALES IN MENTAL DEFECTIVE INSTITUTIONS

\begin{tabular}{|c|c|c|c|c|c|c|c|}
\hline \multirow{2}{*}{ Authors } & \multirow{2}{*}{ Country } & \multirow{2}{*}{$\begin{array}{l}\text { No. } \\
\text { Examined }\end{array}$} & \multirow{2}{*}{$\begin{array}{c}\text { No. } \\
\text { with } 2 \\
\text { Barr } \\
\text { Bodies }\end{array}$} & \multicolumn{4}{|c|}{ Sex Chromosome Constitutions } \\
\hline & & & & $\mathbf{x x x}$ & $\mathbf{X X} / \mathbf{X X X}$ & $\mathbf{x O} / \mathbf{x x x}$ & Others \\
\hline $\begin{array}{l}\text { Fraser et al. (1960) } \\
\text { Johnston et al. (1961) } \\
\text { Breakey (1961) } \\
\text { Sanderson and Stewart } \\
\text { (1961) } \\
\text { Hamerton, Jagiello, and } \\
\text { Kirman (1962) } \\
\text { Maclean et al. (1962) } \\
\text { Unpublished Edinburgh } \\
\text { Observations } \\
\text { Breg et al. (1963) } \\
\text { Davies (1963) } \\
\text { De la Chapelle (1963) } \\
\text { Ridler, Shapiro, and } \\
\text { McKibben (1963) } \\
\text { Anderson et al. (1964) }\end{array}$ & $\begin{array}{l}\text { Scotland } \\
\text { U.S.A. } \\
\text { N. Ireland } \\
\text { Scotland } \\
\text { England } \\
\text { Scotland and } \\
\text { England } \\
\text { U.S.A. } \\
\text { Wales } \\
\text { Finland } \\
\text { England } \\
\text { S. Africa }\end{array}$ & $\begin{array}{r}595 \\
827 \\
140 \\
240 \\
196 \\
1907 \\
\\
1477 \\
727 \\
250 \\
1256 \\
\\
735\end{array}$ & $\begin{array}{c}4 \\
3 \\
1 \star \\
2 \\
8 \\
12 \\
\frac{5}{2} \\
2\end{array}$ & $\begin{array}{r}4 \\
3 \\
- \\
2 \\
7 \\
9 \\
5 \\
2 \\
2\end{array}$ & $\begin{array}{l}- \\
- \\
- \\
- \\
- \\
-\end{array}$ & $\begin{array}{l}z \\
- \\
-\end{array}$ & $\begin{array}{l}\text { 二 } \\
1 \text { X+isochromosome of X long arms } \\
1 \text { XO } \\
1 \text { XO/X+ring chromosomet } \\
1 \text { XO/XY } \\
1 \text { XXXX } \\
3 \text { XO } \\
1 \text { XO/X + partly deleted X } \\
1 \text { XO/X + isochromosome of X long arms } \\
1 \text { chromatin-positive female analysed be- } \\
\text { cause of clinical diagnosis of Turner's } \\
\text { syndrome found to have XO/XX con- } \\
\text { stitution } \\
1 \text { XO/X + fragment of } Y \text { (?) }\end{array}$ \\
\hline Totals & & 9249 & 43 & & & & \\
\hline
\end{tabular}

* No chromosome studies made.

t Fisher (1965).

TABLE VI

INCIDENCE OF SUPERNUMERARY SEX CHROMATIN IN EDINBURGH POPULATION SURVEYS

\begin{tabular}{|c|c|c|c|c|c|c|c|}
\hline \multirow{3}{*}{ Population } & \multicolumn{3}{|c|}{ Males } & \multicolumn{3}{|c|}{ Females } & \multirow{3}{*}{$\begin{array}{l}\text { Male/female } \\
\text { Ratio of Incidence } \\
\text { of Supernumerary } \\
\text { Sex Chromatin }\end{array}$} \\
\hline & \multirow[t]{2}{*}{ No. Examined } & \multicolumn{2}{|c|}{ Chromatin + ve } & \multirow[t]{2}{*}{ No. Examined } & \multicolumn{2}{|c|}{2 Sex Chromatin Bodies } & \\
\hline & & No. & $\%$ & & No. & $\%$ & \\
\hline $\begin{array}{l}\text { Babies born in hospital or at home } \\
\text { Mental hospital patients } \\
\text { Mental deficiency institution patients }\end{array}$ & $\begin{array}{r}12,456 \\
6,000 \\
4,178\end{array}$ & $\begin{array}{l}23 \\
30 \\
41\end{array}$ & $\begin{array}{l}0 \cdot 18 \\
0.50 \\
0.98\end{array}$ & $\begin{array}{r}11,653 \\
7,207 \\
3,384\end{array}$ & $\begin{array}{l}12 \\
17 \\
20\end{array}$ & $\begin{array}{l}0 \cdot 10 \\
0 \cdot 24 \\
0.59\end{array}$ & $\begin{array}{l}1 \cdot 80 \\
2 \cdot 12 \\
1 \cdot 66\end{array}$ \\
\hline
\end{tabular}

schizophrenia rather than to psychosis in general is more doubtful. In considering this problem it is relevant to compare the incidence of $\mathrm{X}$ chromosome abnormalities in schizophrenic patients with that in the residual hospital population, when the groups of schizophrenic, mental defective, and epileptic cases have been abstracted. There were 2477 males in this residual category in the present survey and 6 of them were chromatin positive $(0.24 \%)$. This incidence, though lower than that in the schizophrenic group, does not differ from it significantly, either when the 11 cases with a primary diagnosis of schizophrenia are considered alone $\left(\chi^{2}=0.31\right)$, or when 2 mentally defective patients with schizophrenic features are also included $\left(\chi^{2}=1.08\right.$; $\mathbf{p}=0.3)$. There is a suggestion in our results, therefore, that the apparent association between schizophrenia and $\mathrm{X}$ chromosome anomalies in males may be mainly a reflection of a non-specific influence of the additional chromosome on the development of psychosis.

In females, abnormal sex chromosome complements other than those containing additional $\mathrm{X}$ chromosomes appear to play little part in causing mental abnormalities. None were encountered in the present investigation, and in 11 surveys including 7993 female mental defectives only 5 with an XO cell line were detected (Table V). The incidence was higher in De la Chapelle's survey (1963), but his experience must be regarded as exceptional. In general it may be said that chromatin-negative females are not much more common in mental deficiency institutions, and may be less common in mental hospitals than in the general population. Estimates of the incidence of $\mathrm{X}$ chromosome abnormalities in the general population are based mainly on surveys of newborn babies, and the Edinburgh experience may be taken as representative. The 
surveys included 10,000 girls born in hospital (Maclean et al., 1964) and 1653 girls born at home (unpublished data). No sex chromatin abnormality was detected in the latter group, and the incidence of chromatin-negative girls in the 11,653 newborn females is $0.03 \%$, and of females with 2 sex chromatin bodies, $0 \cdot 10 \%$.

Females with an XXX cell line are overrepresented in mentally defective populations (Table V). 43 were detected among 9249 mentally defective females $(0.46 \%)$, an incidence that is significantly higher than in the newborn. In the present survey, the incidence of the XXX constitution in the general mental hospital population ( $0.24 \%$ ) fell between those of the newborn and the mentally defective.

Mental deficiency again appears to be responsible for part of the increased incidence of sex chromosome abnormalities in the female mental hospital population. Thus, in an estimated population of 391 mentally defective females, there were 3 with XXX sex chromosomes and 1 with $\mathrm{XO} / \mathrm{XXX}$ cell lines. This incidence $(1.02 \%)$ is even higher than that in mental defective institutions $(0.46 \%)$ though the difference is not significant $\left(\chi^{2}=1.68 ; \mathrm{p}=0.2\right)$. Epilepsy did not account for any of the excess of abnormal sex chromosome constitutions in women, but the estimated number of epileptics, 141, is small and therefore this negative finding is of doubtful significance. The diagnosis of schizophrenia, on the other hand, was prominent in women with abnormal sex chromatin, and 7 women were affected in this way. One of the mentally defective patients with $\mathrm{XXX}$ sex chromosomes was said to show schizophrenic features. Four other women with schizophrenia also had XXX sex chromosomes and 2 others had both XX and XXX cell lines. These abnormalities occurred in an estimated population of 2071 patients with schizophrenia, an incidence $(0.34 \%)$ that is less than that in the mentally defectives but is significantly greater than that in the newborn females of the Edinburgh surveys $\left(\chi^{2}=5 \cdot 4\right.$; $\mathrm{p}=0.02$ ). The difficulty in assessing this finding in females is similar to that in chromatin-positive males. The propriety of making the diagnosis of schizophrenia in patients with abnormal sex chromosome constitutions has been called in question and Kidd, Knox, and Mantle (1963), in studying the mental disorders seen in association with additional $\mathrm{X}$-chromosomes in women, and Hambert (1966) reviewing similarly affected males, preferred to analyse the disorders under symptom complexes. Nevertheless, there appears to be no doubt about the association of abnormal sex chromosome constitution with mental disturbance. Kidd et al. (1963), after examining a number of patients detected in the present survey and in a survey of mental defectives (Maclean et al., 1962), called attention to the high incidence of psychosis in women with an $\mathrm{XXX}$ chromosome constitution, not only in mental hospitals but also in mental deficiency institutions. For the purpose of this discussion it is perhaps beside the point to attempt to differentiate between schizophrenia and other forms of psychosis in women, since the incidence of abnormal sex chromosome constitutions in patients diagnosed as suffering from schizophrenia does not differ significantly from that in the residual population (Table III), even when the mentally defective patient with schizophrenia is included $\left(\chi^{2}=1.88 ; 0.2>p>0 \cdot 1\right)$.

Hambert (1966) concluded that the main cause of the personality and behaviour disorders in Klinefelter's syndrome must be attributed to the effect of the chromosome imbalance in the cells of the cerebrum. Obviously the effect that additional $\mathbf{X}$ chromosomes have upon mental development places those affected in this way at a disadvantage in their family and social milieu, without necessarily causing severe mental retardation. In chromatinpositive males, the further disadvantage of testicular atrophy after puberty is added, and it is perhaps little wonder that a proportion of men with this double handicap fail to adapt themselves adef quately to adult life. Hambert (1966) noted, if these patients, the prevalence of a passive-aggres sive disposition, weak libido, and low intensity of personality, and in some of the psychotic patients, megalomania and short episodes of mania.

The influence of the additional $\mathrm{X}$ chromosome in women is probably less complex than in men, since gonadal abnormalities are comparatively rare in women with $3 \mathrm{X}$ chromosomes except when an XO cell line is also present or when one of the $\mathrm{X}$ chromosomes is abnormal. In the present series, for example, menstruation and the external genitalia were normal in the majority of women with sex chromatin abnormalities (Table II). It is, therefore, relevant to compare the ratio of the incidence of the chromatin-positive males to that of females with 2 sex chromatin bodies in 3 Edinburgh population surveys (Table $\mathrm{V}$ ), in an attempt to assess the influence of hypogonadism in initiating mental breakdown in chromatin-positive men. It will be seen that the ratios are similar in newborn babies, mental hospital patients, and the mental defectives. The more damaging karyotypes are, of course, concentrated in the mental deficiency group, and when males with more than one sex-chromatin body or with more than one $\mathrm{Y}$ chromosome are omitted from consideration the ratios become $1 \cdot 71,2 \cdot 05$, and $1 \cdot 28$, respectively. The $M: F$ ratio, therefore, is 
slightly higher in the mental hospital population, but the difference is insignificant. Similarly if gynaecomastia is taken as an index of the degree of hormonal disturbance in chromatin-positive males, it is found that it is commoner in such patients in mental hospitals than in mental deficiency institutions, but the difference is slight (Court Brown, 1967). Therefore, neither the difference in the incidence of gynaecomastia nor the difference in the $\mathrm{M}: \mathrm{F}$ ratios in the various population groups with additional $\mathrm{X}$ chromosomes are such as to suggest that hypogonadism and its consequences play more than a subsidiary role in the pathogenesis of mental illnesses experienced by a proportion of chromatinpositive males.

The evidence, therefore, is suggestive that additional $\mathrm{X}$ chromosomes have a disturbing effect upon mental development, which is not restricted to intellectual maturation and is not mediated mainly through hormonal imbalance. But it remains to be decided whether the extra $\mathrm{X}$ chromosomes are alone responsible or whether they merely exaggerate inborn predispositions to mental illness determined by other factors. In Hambert's series, for instance, a history of mental instability was frequent amongst the relatives of chromatin-positive males. In the meantime, however, it seems reasonable to assume that additional $\mathrm{X}$ chromosomes play a significant part in initiating a variety of disturbances including mental deficiency, psychosis, and epilepsy.

\section{Summary}

The prevalence of sex chromatin abnormalities in 6000 male and 7207 female mental hospital patients was studied by means of the buccal smear technique. 30 of the men were chromatin positive, and 17 of the women had 2 sex chromatin bodies in some or all of their cells. None of the women was chromatin negative. Chromosome analyses were carried out on the patients with abnormal sex chromatin. At attempt is made to assess the influence of these abnormalities in the development of mental illness, and it is concluded that X chromosomes additional to the normal complement may play a significant part in initiating a variety of mental disturbances.

The survey was made possible by a grant from the Medical Research Council for technical assistance and expenses to one of us (N.M.), and by the hard work of Mr. John Mitchell, Mrs. Elizabeth Greenhill, Mrs. B. Trower, Mrs. Marlene Deans, Mr. Norman Davidson, Miss Catherine Cunningham, Miss Kareen Livingstone, and Miss Linda Yorston, who assisted in taking the buccal smears and were reponsible for their screening. We are indebted to the following Physician-Superintendents for allowing us to visit their hospitals, and to their staff for their kind and tolerant co-operation: Drs. G. M. Bell, Thomas Dymock, Hunter Gillies, A. B. Hegarty, E. O. Lundholm, Iain McCammond, J. Macleod, Angus MacNiven, A. K. M. Macrae, J. W. Macpherson, H. J. Brawn Miller, the late T. A. Munro, R. H. Park, J. M. Rosie, David Ross, A. P. Russel, H. Stalker, and G. E. Swinney. Mrs. Pauline Bull and Mrs. Ella F. amilton gave valuable clerical assistance. It is a pleasure to acknowledge all this essential help, and to express our gratitude for the co-operation we received throughout the survey.

\section{REFERENCES}

Anderson, I. F., Goeller, E. A., and Wallace, C. (1964). Sex chromosome abnormalities in a population of 1,662 mental defectives. S. Afr. med. F., 38, 346.

Bond, I. K., and Margulies, A. I. (1964). Paranoid schizophrenia in a patient with Klinefelter's syndrome. Canad. psychiat. Ass. F., $9,439$.

Breakey, W. R. (1961). Sex chromatin analyses in a mentally defective population. F. Anat. (Lond.), 95, 618 .

Breg, W. R., Castilla, E. E., Miller, O. J., and Cornwell, J. G. (1963). Sex chromatin and chromosome studies in 1,562 institutionalised mental defectives. F. Pediat., 63, 738.

Carr, D. H., Barr, M. L., and Plunkett, E. R. (1961). A probable XXYY sex determining mechanism in a mentally defective male with Klinefelter's syndrome. Canad. med. Ass. f., 84, 873.

Court Brown, W. M. (1967). Human Population Cytogenetics. North Holland Publishing Co., Amsterdam.

, Harnden, D. G., Jacobs, P. A., Maclean, N., and Mantle, D. J. (1964a). Abnormalities of the sex chromosome complement in man. Spec. Rep. Ser. med. Res. Coun. (Lond.), No. 305.

, Mantle, D. J., Buckton, K. E., and Tough, I. M. (1964b). Fertility in an XY/XXY male married to a translocation heterozygote. F. med. Genet., 1, 35.

Davies, T. S. (1963). Buccal smear surveys for sex chromatin. Brit. med. F., 1, 1541.

De la Chapelle, A. (1963). Sex chromosome abnormalities among the mentally defective in Finland. F. ment. Defic. Res., 7, 129.

Ferguson-Smith, M. A. (1966). Sex chromatin, Klinefelter's syndrome, and mental deficiency. In The Sex Chromatin, p. 277. Ed. by K. L. Moore. W. B. Saunders, Philadelphia.

Fisher, G. W. (1965). Ring chromosome mosaicism in a severely subnormal child with multiple congenital malformations. f. ment. Defic. Res., 9, 39.

Fraser, J. H., Campbell, J., MacGillivray, R. C., Boyd, E., and Lennox, B. (1960). The XXX syndrome. Frequency among mental defectives and fertility. Lancet, 2, 626.

Hambert, G. (1964). Positive sex chromatin in men with epilepsy. Acta med. scand., 175, 663.

(1966). Males with Positive Sex Chromatin. Munksgaard, Kobenhavn.

Hamerton, J. L., Jagiello, G. M., and Kirman, B. H. (1962). Sexchromosome abnormalities in a population of mentally defective children. Brit. med. F., 1, 220.

Harnden, D. G. (1960). A human skin culture technique used for cytological examinations. Brit. F. exp. Path., 41, 31.

Jagiello, G. (1961). Personal communication to Polani (1961).

Johnston, A. W., Ferguson-Smith, M. A., Handmaker, S. D., Jones, H. W., and Jones, G. S. (1961). The triple-X syndrome. Clinical, pathological, and chromosomal studies in three mentally retarded cases. Brit. med. F., 2, 1046.

Kidd, C. B., Knox, R. S., and Mantle, D. J. (1963). A psychiatric investigation of triple-X chromosome females. Brit. $\mathcal{f}$. psychiat., $109,90$.

Maclean, N. (1966). Sex chromatin surveys of newborn babies. In The Sex Chromatin. Ed. by K. L. Moore. W. B. Saunders, Philadelphia.

, Harnden, D. G., Court Brown, W. M., Bond, J., and Mantle, D. J. (1964). Sex-chromosome abnormalities in newborn babies. Lancet, 1, 286.

, Mitchell, J. M., Harnden, D. G., Williams, J., Jacobs, P. A., Buckton, K. A., Baikie, A. G., Court Brown, W. M., McBride, J. A., Strong, J. A., Close, H. G., and Jones, D. C. (1962). A survey of sex-chromosome abnormalities among 4514 mental defectives. ibid., 1, 293. 
Money, J., and Hirsch, S. R. (1963). Chromosome anomalies, mental deficiency and schizophrenia. Arch. gen. Psychiat., 8, 242.

Moore, K. L., and Barr, M. L. (1955). Smears from the oral mucosa in the detection of chromosomal sex. Lancet, $2,57$.

Moorhead, P. S., Nowell, P. C., Mellman, W. J., Battips, D. M., and Hungerford, D. A. (1960). Chromosome preparations of leukocytes cultured from human peripheral blood. Exp. Cell Res., 20, 613.

Nielsen, J. (1964). Prevalence of Klinefelter's syndrome in patients with mental disorders. Lancet, 1, 1109.

Polani, P. E. (1961). Sex chromosome aberrations in relation to neuropsychiatry. Proc. roy. Soc. Med., 54, 672.
Prader, A., Schneider, J., Züblin, W., Francés, J. M., and Rüedi, K. (1958). Die Häufigkeit des echten, chromatin-positiven $\Omega$ Klinefelter-Syndroms und seine Beziehungen zum Schwachsinn. Schrveiz. med. Wschr., 88, 917.

Raphael, T., and Shaw, M. W. (1963). Chromosome studies in schizophrenia. f. Amer. med. Ass., 183, 1022.

Ridler, M. A. C., Shapiro, A., and McKibben, W. R. (1963). Sex CS chromatin abnormalities in female subnormal patients. Brit. 7.7 psychiat., 109, 390.

Sanderson, A. R., and Stewart, J. S. S. (1961). Nuclear sexing with aceto-orcein. Brit. med. F., 2, 1065.

Tedeschi, L. G., and Freeman, H. (1962). Sex chromosomes in male schizophrenics. Arch. gen. Psychiat., 6, 109. 